\title{
Effect of Ethanol Extract of Moringa oleifera Leaf on Nissl Granules, Immunohistochemistry of Inferior Colliculus and Oxidative System Following Quinine Toxicity in Wistar Rats
}

\author{
Idorenyin Umoh ${ }^{1, ~ *}$, Theresa Ekanem², Herbert Mbagwu ${ }^{3}$, Justina Udotong ${ }^{4}$ \\ ${ }^{1}$ Department of Anatomy, Faculty of Basic Medical Sciences, University of Uyo, Uyo, Nigeria \\ ${ }^{2}$ Department of Anatomy, Faculty of Basic Medical Sciences, University of Calabar, Calabar, Nigeria \\ ${ }^{3}$ Department of Pharmacology and Toxicology, Faculty of Pharmacy, University of Uyo, Uyo, Nigeria \\ ${ }^{4}$ Department of Biochemistry, Faculty of Basic Medical Sciences, University of Uyo, Uyo, Nigeria
}

\author{
Email address: \\ umohidorenyin_dr@yahoo.com (I. Umoh) \\ ${ }^{*}$ Corresponding author
}

\section{To cite this article:}

Idorenyin Umoh, Theresa Ekanem, Herbert Mbagwu, Justina Udotong. Effect of Ethanol Extract of Moringa oleifera Leaf on Nissl Granules, Immunohistochemistry of Inferior Colliculus and Oxidative System Following Quinine Toxicity in Wistar Rats. International Journal of Clinical and Developmental Anatomy. Vol. 7, No. 1, 2021, pp. 6-17. doi: 10.11648/j.ijcda.20210701.12

Received: September 30, 2020; Accepted: October 22, 2020; Published: March 10, 2021

\begin{abstract}
The metabolite of Quinine, 3-hydroxyquinine is the active substance and more toxic than quinine hence, it can exert pro-oxidant effect in the body. In this study, the effect of ethanol leaf extract of Moringa oleifera was evaluated against quinine toxicity on nissl granules, immunohistochemistry of inferior colliculus and oxidative system of Wistar rats. Fifty Wistar rats weighing $180-200 \mathrm{~g}$ were alloted into 10 groups of 5 rats each. Group 1 served as control while Groups 2 to 10 were the treatment groups. Groups $2-4$ received 10,20 and $30 \mathrm{mg} / \mathrm{kg}$ body weight of quinine hypochloride injection intramuscularly eight hourly for 7 days. Groups $5-7$ were orally administered 250,500 and $750 \mathrm{mg} / \mathrm{kg}$ body weight of $M$. oleifera leaf extract daily for 7 days respectively. Group 8 received $250 \mathrm{mg} / \mathrm{kg}$ of leaf extract orally and intramuscular (IM) $10 \mathrm{mg} / \mathrm{kg}$ of quinine; Group 9 was treated with oral $500 \mathrm{mg} / \mathrm{kg}$ of the extract and IM $20 \mathrm{mg} / \mathrm{kg}$ of quinine while Group 10 received $750 \mathrm{mg} / \mathrm{kg}$ of the extract orally and IM $30 \mathrm{mg} / \mathrm{kg}$ of quinine for 7 days. Results revealed that quinine significantly (p < 0.05 ) decreased the activities of anti-oxidative enzymes (superoxide dismutase and catalase) and increased lipid peroxidation (malondialdehyde, MDA) in treated rats. However, Moringa oleifera leaf extract showed significant increase in the activities of anti-oxidant enzymes and decreased lipid peroxidation. Histomorphological and immunohistochemical observations revealed that quinine caused neuronal distortions, nuclear degenerations, and depletion of Nissl granules, vascular congestions and vacuolations and increased astrogliosis in the inferior colliculus. Incorporation of the extract to the quinine treated groups revealed neuronal regenerations, increased staining intensity and density of the Nissl granules, reduced astrogliosis and restoration in the inferior colliculuscyto-architectures. In conclusion, Moringa oleifera leaf extract can be used to ameliorate the adverse effects of quinine toxicity on inferior colliculus.
\end{abstract}

Keywords: Quinine, Moringa oleifera, Inferior Colliculus, Nissl Granules, Oxidative Enzymes

\section{Introduction}

Non-tolerability and non-compliance of patients to medications may be as a result of the adverse effects of the drugs on them [1] This could also be one of the causes that may result in drug resistance by the offending organisms to the drugs. Adverse effects of drugs could be caused by reactive oxygen species which can lead to oxidative damage of body tissues $[2,1]$. Quinine is recommended to be used as an antimalarial drug especially when artesunate is unavailable [3]. It is safe even in the first trimester of pregnancy [4]. Although quinine occurs naturally in the bark 
of the cinchona tree, it has been synthesized in the laboratory [4]. Quinine is rapidly absorbed both orally and parenterally, reaching peak concentration within $1-3$ hours. It is distributed throughout the body fluid and is highly protein bound mainly to alpha $(\alpha)-1$ acid glycoprotein and the binding capacity in plasma is concentration dependent, and the levels of alpha-1 acid glycoprotein [4]. Quinine is incorporated in minute quantities as a flavor component in tonic water and bitter lemon. It is used in treating lupus erythromatosus and arthritis. In addition to its poor tolerability and poor compliance with complex dose regimes [5], quinine has several setbacks. It is known for its ototoxicity and neurotoxicity [6]. The side effects commonly encountered at therapeutic concentration and referred to as cinchonism include mild form of tinnitus, slight impairment of hearing, headache and nausea. More marked adverse effects are vertigo, vomiting, abdominal pains, marked auditory loss and visual symptoms including loss of vision [4]. Permanent blindness with standard dose of quinine has been documented [3].

In recent years, several plant extracts and other natural products have been tested for their antioxidant properties. Furthermore, the use of antioxidant supplements can reverse or minimize the oxidative damage to host caused by the free radicals released by the use of antimalarial drugs [7]. Most of plants used for medicinal purposes have been correlated to their possession of antioxidant activity [8,9]. Antioxidants quench, scavenge and suppress the formation of reactive oxygen species and free radicals or oppose their actions [1012]. Moringa oleifera is an economically important tree and vegetable. Preliminary evidence suggest that it has an antioxidant and anti-inflammatory potency [7, 13]. Moringa oleifera is an herbal plant with immense medicinal value because of its antioxidant properties [14, 15]. The plant is also a rich source of vitamins and antioxidants. It contains good amount of proteins, minerals, vitamin A, vitamin $\mathrm{B}$ complex, essential amino acids and high content of vitamin $\mathrm{E}$ [16].

In view of the antioxidant properties of Moringa oleifera leaf and its richness in minerals and vitamins, this research was aimed at examining its effect on nissl substances, histomorphology of inferior colliculus, some oxidative enzymes, lipid peroxidation following quinine toxicity in adult Wistar rats.

\section{Materials and Method}

\subsection{Animal Care and Protocols}

Fifty (50) male Wistar rats weighing $180-200 \mathrm{~g}$ used in this study were obtained from the Animal House of the Faculty of Basic Medical Science (FBMS), University of Uyo, Uyo, Nigeria. Approval for the study was obtained from the Faculty Animal Care and Use Research and Ethical Committee and the research was strictly conducted according to the international guidelines for the care and use of Laboratory animals of the Faculty Animal Care and Use
Committee. The animals were randomly grouped into 10 (ten) groups with 5 rats in each group and were fed with growers mash (Pfizer Nigeria Ltd) and allowed drinking water ad libitum.

\subsection{Preparation of Plant Material and Drug}

The Moringa oleifera leaf samples of the same species and varieties were collected from a local farm in Uyo, Akwa Ibom State, washed and transported under hygienic condition. The leaves were identified and authenticated by a taxonomist in the Department of Botany and Ecological Studies, Faculty of Science, University of Uyo, Uyo with the Voucher No. A (50) i. Moringa oleifera leaf extract concentrate was prepared by ethanol extraction using Percolation Method described by United States Pharmcopoeia Convention Inc (2000). The leaves were carefully washed in clean water and dried under shade for about 7 days. The air-dried leaves were powdered and macerated in $70 \%$ ethanol. After mixing thoroughly in a suitable round bottom flask for 72 hours at room temperature, the extract was filtered with Whatman filter paper size No. 1 and the filtrate was then concentrated in water bath to dryness at $40^{\circ} \mathrm{C}$. The concentrated extract was preserved in refrigerator at the temperature of $-4^{\circ} \mathrm{C}$ until commencement of the research.

\subsection{Determination of Acute Toxicityand Drug Preparation}

Acute toxicity testing [lethal dose $\left(\mathrm{LD}_{50}\right)$ ] of the extract was determined using modified Lorke's method (1983) [17], in two stages using Swiss albino mice, age 6 to 8 weeks. The mice were obtained from the animal house of the Faculty of Basic Medical Science (FBMS), University of Uyo, Uyo. The extract was administered orally. In the first stage, the animals (mice) received 1000, 2000, 3000, 4000, and $5000 \mathrm{mg} / \mathrm{kg}$ of the ethanol extract of moringa oleifera leaves. In the second stage, the animals (mice) received 2300, 2400, 2500,2600 , and $2700 \mathrm{mg} / \mathrm{kg}$ of the ethanolic extract of moringa oleifera leaf. All the experimental mice were observed for physical signs of acute toxicity such as decreased respiration, limbed body and death for 12 hours and the number of animals that died within 24 hours recorded. According to modified Lorke's method [17], the $\left(\mathrm{LD}_{50}\right)$ was calculated which was $2500 \mathrm{mg} / \mathrm{kg}$.

The stock solution was prepared and calculated by dissolving $2500 \mathrm{mg} / \mathrm{kg}$ of the extract in $20 \mathrm{mls}$ of distilled water to get the stock solution of $125 \mathrm{mg} / \mathrm{ml}$. The therapeutic dose was calculated using $10 \%$ of the lethal dose as $250 \mathrm{mg} / \mathrm{kg}$ body weight. The volume of the stock solution used was calculated using Tedong equation

$$
\mathrm{V}=(\mathrm{DXP}) / \mathrm{C}
$$

Where;

$\mathrm{D}=$ group dose used $(\mathrm{mg} / \mathrm{kg})$

$\mathrm{P}=$ animal body weight $(\mathrm{kg})$

$\mathrm{C}=$ Conc. of the stock solution

$\mathrm{V}=$ volume of the experimental drug $(\mathrm{ml})$

Injectable quinine hypochloride was obtained from 
Buchler GmbH Germany. Appropriate conversion practice was used to calculate the therapeutic and experimental dosages determined per kilogramme $(\mathrm{kg})$ body weight of the animals. The injections were given intramuscularly on the thigh

\subsection{Experimental Design}

The experimental animals were sorted randomly into ten groups (Groups 1 - 10) with five rats in each Group. Group 1 was taken as the control group and was administered with distilled water. Groups 2, 3 and 4 were given $10 \mathrm{mg} / \mathrm{kg}, 20$ $\mathrm{mg} / \mathrm{kg}$ and $30 \mathrm{mg} / \mathrm{kg}$ of quinine hypochloride injections intramuscularly respectively eight (8) hourly for seven days. Groups 5, 6 and 7 were administered 250, 500 and 750 $\mathrm{mg} / \mathrm{kg}$ of extract of $M$. oleifera leaf orally, respectively for 7 days. Groups 8, 9 and 10 received concomitantly, $250 \mathrm{mg} / \mathrm{kg}$ of $M$. oleifera leaf extract daily and $10 \mathrm{mg} / \mathrm{kg}$ of quinine 8 hourly, $500 \mathrm{mg} / \mathrm{kg}$ of $M$. oleifera leaf extract daily and 20 $\mathrm{mg} / \mathrm{kg}$ body weight of quinine 8 hourly and $750 \mathrm{mg} / \mathrm{kg}$ of $M$. oleifera leaf extract daily and $30 \mathrm{mg} / \mathrm{kg}$ of quinine 8 hourly for 7 days respectively. The administration of quinine and ethanol leaf extract of $M$. oleifera lasted for 7 days.

At the end of the experiment, the animals were sacrificed under chloroform inhalational anaesthesia then the blood samples collected by intracardiac puncture for assay of antioxidant enzymes activity while the experimental animals were perfused with phosphate buffer solution (PBS) and the brain tissues harvested, processed and stained for histological studies. A section of the brain was homogenized and the brain homogenate used for evaluation of indices of lipid peroxidation.

\subsection{Determination of Antioxidant Enzyme Activity and Lipid Peroxidation}

Quantitative determination of whole-cell catalase activity was accomplished using a protocols described by Herbert [18] and Beers and Sizer [19]. SOD activity was assayed according to the method by Kakkar, Das and Viswanathan, [20]. Thiobarbituric acid reactive substance, the last product in lipid peroxidation pathways was estimated by the methods of Nichaus and Samuelsson [21].

\subsection{Histopathological Analysis}

The experimental animals were perfused with phosphate buffer solution (PBS); shortly after the perfusion, brain tissues were harvested and fixed immediately in neutral buffered formalin for histomorphological evaluation. Haematoxylin and Eosin method was used for general histologic evaluation, Cresyl Fast Violet Method [22] for Nissl Granules and GFAP Immunohistochemistry Protocol were used to evaluate the reactive astrocytes of the inferior colliculus of the experimental animal.

\subsection{Statistical Analysis}

The data obtained were subjected to analysis of variance (ANOVA) at 5\% level of significance to establish the statistical differences between means of each group. Duncan's New Multiple Range Test was used to compare the means as described by Steel and Torrie [23].

\section{Results}

\subsection{Effect of Quinine and Ethanol Leaf Extract of Moringa oleifera on the Histomorphology of Inferior Colliculus}

The general histology of the inferior colliculus $(\mathrm{H}$ and $\mathrm{E}$ Method) is presented in Figure 1. Photomicrograph HE01 revealed Inferior colliculus of control group with normal area of neuronal cell body, and neuronal density. The nerve fibres are not thickened. Photomicrograph HE02, HE03 and HE04 represent Inferior colliculus of Group $2(10 \mathrm{mg} / \mathrm{kg}$ bw of quinine), Group 3 (20 mg/kg body weight of quinine) and Group $4(30 \mathrm{mg} / \mathrm{kg}$ body weight of quinine). Observed features include neuronal cell degeneration, reduced neuronal density and thickened nerve fibers. The histology of Groups $5(250 \mathrm{mg} / \mathrm{kg}$ of $M$. oleifera $), 6(500 \mathrm{mg} / \mathrm{kg}$ of $M$. oleifera $)$ and $7(750 \mathrm{mg} / \mathrm{kg}$ of $M$. oleifera $)$ are represented in photomicrograph HE05, HE06 and HE07. Normal neuronal cell, neuronal density and nerve fibres were observed. The photomicrograph of Group 8 (HE08) treated concomitantly with $10 \mathrm{mg} / \mathrm{kg}$ of quinine and $250 \mathrm{mg} / \mathrm{kg}$ of $M$. oleifera revealed normal neuronal cell and neuronal density, the nerve fibres are not thickened. Photomicrograph HE09, the histology of Group $9(20 \mathrm{mg} / \mathrm{kg}$ of quinine and $500 \mathrm{mg} / \mathrm{kg}$ of $M$. oleifera concomitantly), revealed slight neuronal cell degeneration, slight hypertrophy of neuronal cells and slightly thickened irregular nerve fibers and reduced neuronal density. The histology of Group 10 (HE10) treated concomitantly with $30 \mathrm{mg} / \mathrm{kg}$ of quinine and $750 \mathrm{mg} / \mathrm{kg}$ of $M$. oleifera showed features such as slight neuronal cell degeneration, thickened irregular nerve fibers and reduced neuronal density.

\subsection{Effect of Quinine and Ethanol Leaf Extract of Moringa oleifera on the Immunohistochemistry of Inferior Colliculus}

The results of the immunohistochemistry studies on the inferior colliculus in the present study, using CFV and GFAP staining methods are presented in Figures 2 and 3 respectively. The photomicrograph labelled NS01 representing Group 1 (control) revealed neuron cell body, with prominent nucleus and densely packed nissl granules within normal cellular cytoarchitecture. The inferior colliculus of Groups $2(10 \mathrm{mg} / \mathrm{kg}$ body weight of quinine $\mathrm{NS} 02), 3$ (20 mg/kg body weight of quinine - NS03) and 4 (30 mg/kg body weight of quinine - NS03) revealed cell body shrinkage of neurons, Pyknotic Nucleus shrinkage, Karyolitic Nucleus and Nissl granules depletion. Administration of ethanol leaf extract of $M$. oleifera to Groups 5 (250 mg/kg body weight of M. oelifera - NS05), 6 $(500 \mathrm{mg} / \mathrm{kg}$ body weight - NS06) and $7(750 \mathrm{mg} / \mathrm{kg}$ body weight - NS07) showed Inferior colliculus with cell body of 
neurons, containing Nucleus and densely packed Nissl granules within cytoplasmic content. Concomitant administration of $10 \mathrm{mg} / \mathrm{kg}$ of quinine and $250 \mathrm{mg} / \mathrm{kg}$ of $M$. oleifera in group 8 (NS08) revealed Inferior colliculus with cell body of neurons, containing Nucleus and reduced concentration of densely packed Nissl granules within cytoplasmic content. However, the cytoarchitecture of Group 9 labelled NS09 $(20 \mathrm{mg} / \mathrm{kg}$ of quinine and $500 \mathrm{mg} / \mathrm{kg}$ of $M$. oleifera) revealed Inferior colliculus with cell body shrinkage of neurons, containing Karyolitic Nucleus and nissl granules depletion within cytoplasmic content. Similarly, the cytoarchitecture of Group 10 labelled NS10 $(30 \mathrm{mg} / \mathrm{kg}$ of quinine and $750 \mathrm{mg} / \mathrm{kg}$ of $M$. oleifera) revealed Inferior colliculus with cell body shrinkage of neurons, containing Karyolitic Nucleus and nissl granules depletion within cytoplasmic content.

Photomicrographs AS01 - AS10 represent the immunohistochemistry (GFAP Method) of the inferior colliculus of experimental animals in Group $1-10$ respectively and they show astrocytes reactivity. Normal cellular architecture and no astrocytes reactivity were observed in the photomicrograph of the control group labelled AS01. Administration of 10, 20 and $30 \mathrm{mg} / \mathrm{kg}$ bw of quinine to Groups 2, 3 and 4 respectively revealed severe reactive astrocytes (AS) with thick process. Vacuolation in the stroma (arrows) was also observed in Group 4. Administration of 250,500 and $750 \mathrm{mg} / \mathrm{kgbw}$ of M. oleifera to Groups 6, 7 and 8 respectively revealed Inferior colliculus with normal cellular profile. Normal cellular profile was also observed in Group 8 following treatment with $10 \mathrm{mg} / \mathrm{kg}$ of quinine and $250 \mathrm{mg} / \mathrm{kg}$ of $M$. oleifera concomitantly. The inferior colliculus of Group 9 treated concomitantly with 20 $\mathrm{mg} / \mathrm{kg}$ of quinine and $500 \mathrm{mg} / \mathrm{kg}$ of $M$. oleifera showed reactive astrocytes and neuronal cell. Astrocytes with thick processes were observed in the inferior colliculus of animals treated concomitantly with $30 \mathrm{mg} / \mathrm{kg}$ of quinine and 750 $\mathrm{mg} / \mathrm{kg}$ of $M$. oleifera.

\subsection{Effect of Ethanol Leaf Extract of Moringa oleifera and Quinine on Oxidative Stress Indices}

The effect of ethanol leaf extract of Moringa oleifera and quinine on the MDA level in adult Wistar rats is presented in Figure 4. The results showed that rats in Groups 2, 3 and 4 which were treated with $10 \mathrm{mg} / \mathrm{kg}, 20 \mathrm{mg} / \mathrm{kg}$ and $30 \mathrm{mg} / \mathrm{kg}$ of quinine respectively had significant increase $(p<0.01)$ in
MDA level compared with control group. Moringa oleifera leaf extract inhibited the amount of MDA generated (and thus lipid peroxidation) significantly $(p<0.01)$ as observed in Groups 5, 6 and 7 rats. Thus, the decrease in the MDA level on administration of the leaf extract indicates the role of the extracts as an antioxidant. The results revealed MDA level was high in Groups 2, 3 and 4 on administration of 10, 20 and $30 \mathrm{mg} / \mathrm{kg}$ of quinine respectively but low in Groups 5, 6 and 7 on administration of 250,500 and $750 \mathrm{mg} / \mathrm{kg}$ of $M$. oleifera leaf extract respectively. The MDA level in Group 8 $(10 \mathrm{mg} / \mathrm{kg}$ of quinine and $250 \mathrm{mg} / \mathrm{kg}$ of $M$. oleifera leaf extract concomitantly) revealed no significant difference ( $p>$ 0.01 ) when compared with control group. The MDA level in the group treated with $10 \mathrm{mg} / \mathrm{kg}$ of quinine and $250 \mathrm{mg} / \mathrm{kg}$ of $M$. oleifera leaf extract concomitantly significantly decreased $(\mathrm{p}<0.01)$ compared with Group 2 which received $10 \mathrm{mg} / \mathrm{kg}$ of quinine. Groups $9(20 \mathrm{mg} / \mathrm{kg}$ of quinine and $500 \mathrm{mg} / \mathrm{kg}$ of M. oleifera leaf extract concomitantly) and Group 10 (30 $\mathrm{mg} / \mathrm{kg}$ of quinine and $750 \mathrm{mg} / \mathrm{kg}$ of $M$. oleifera leaf extract concomitantly) showed a significant increased $(p<0.01)$ in MDA level when compared with control. Comparing Groups 9 and 10 with Groups 3 (20 mg/ $\mathrm{kg}$ of quinine) and 4 (30 $\mathrm{mg} / \mathrm{kg}$ of quinine) respectively showed a significant decrease $(\mathrm{p}<0.01)$ in MDA level in Groups 9 and 10 .

The effects of ethanol extract of $M$. oleifera leaf extract and quinine on antioxidant enzymes are shown in Figures 5 and 6 . The results revealed that quinine significantly $(\mathrm{p}<$ 0.01 ) decreased superoxide dismutase (SOD) and catalase (CAT) activities in Groups2, 3 and 4 rats treated with 10, 20 and $30 \mathrm{mg} / \mathrm{kg}$ of quinine respectively when compared to the control group. All doses of ethanol extract of $M$. oleifera leaf significantly increased SOD and CAT activities when compared with the control group $(\mathrm{p}<0.01)$ The antioxidant enzymatic activities (SOD and CAT) were low in Groups 2, 3 and 4 on administration of quinine as observed but high in Groups 5, 6 and 7 on administration of Moringa oleifera leaf extracts. There was no significant difference $(p>0.05)$ in SOD and CAT activities of Group 8 when compared with the control group but significantly increased $(p<0.01)$ compared with Group 2. The SOD and CAT activities in Group 2 were significant decreased $(\mathrm{p}<0.01)$ when compared with the control group. There was significant increase in the activity of SOD and CAT in Groups 9 and 10 when compared with Groups 3 and 4 respectively. 

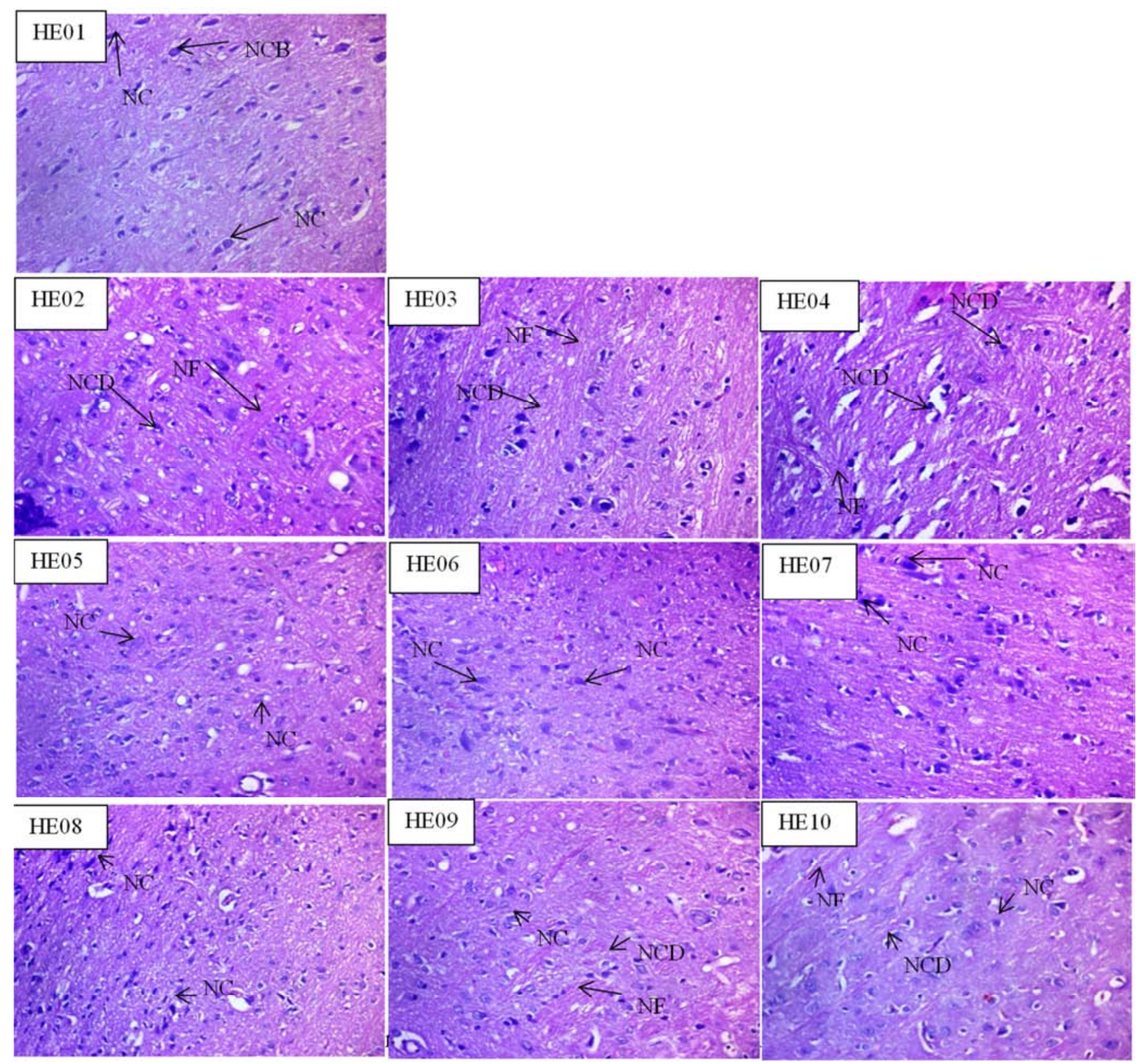

Figure 1. Photomicrographs of the inferior colliculus of experimental animals showing neuronal cells and cellular cyto-architecture following the administration of quinine and ethanol leaf extract of Moringa oleifera. Neuronal cell (NC); Nerve Fibres (NF); Neuronal Cell Degeneration (NCD). (H and E Method, Mag X400).

Photomicrographs HE01 - HE10 represent histology of Groups 1 - 10 respectively. Group 1 - Control; Group $2-10 \mathrm{mg} / \mathrm{kg}$ of quinine; Group 3 - $20 \mathrm{mg} / \mathrm{kg}$ of quinine; Group $4-30 \mathrm{mg} / \mathrm{kg}$ of quinine; Group $5-250 \mathrm{mg} / \mathrm{kg}$ of M. oleifera; Group $6-500 \mathrm{mg} / \mathrm{kg}$ of M. oleifera; Group $7-750 \mathrm{mg} / \mathrm{kg}$ of M. oleifera; Group $8-10 \mathrm{mg} / \mathrm{kg}$ of quinine and $250 \mathrm{mg} / \mathrm{kg}$ of $M$. oleifera concomitantly; Group $9-20 \mathrm{mg} / \mathrm{kg}$ of quinine and $500 \mathrm{mg} / \mathrm{kg}$ of $M$. oleifera concomitantly; Group $10-30 \mathrm{mg} / \mathrm{kg}$ of quinine and $750 \mathrm{mg} / \mathrm{kg}$ of $M$. oleifera concomitantly. 

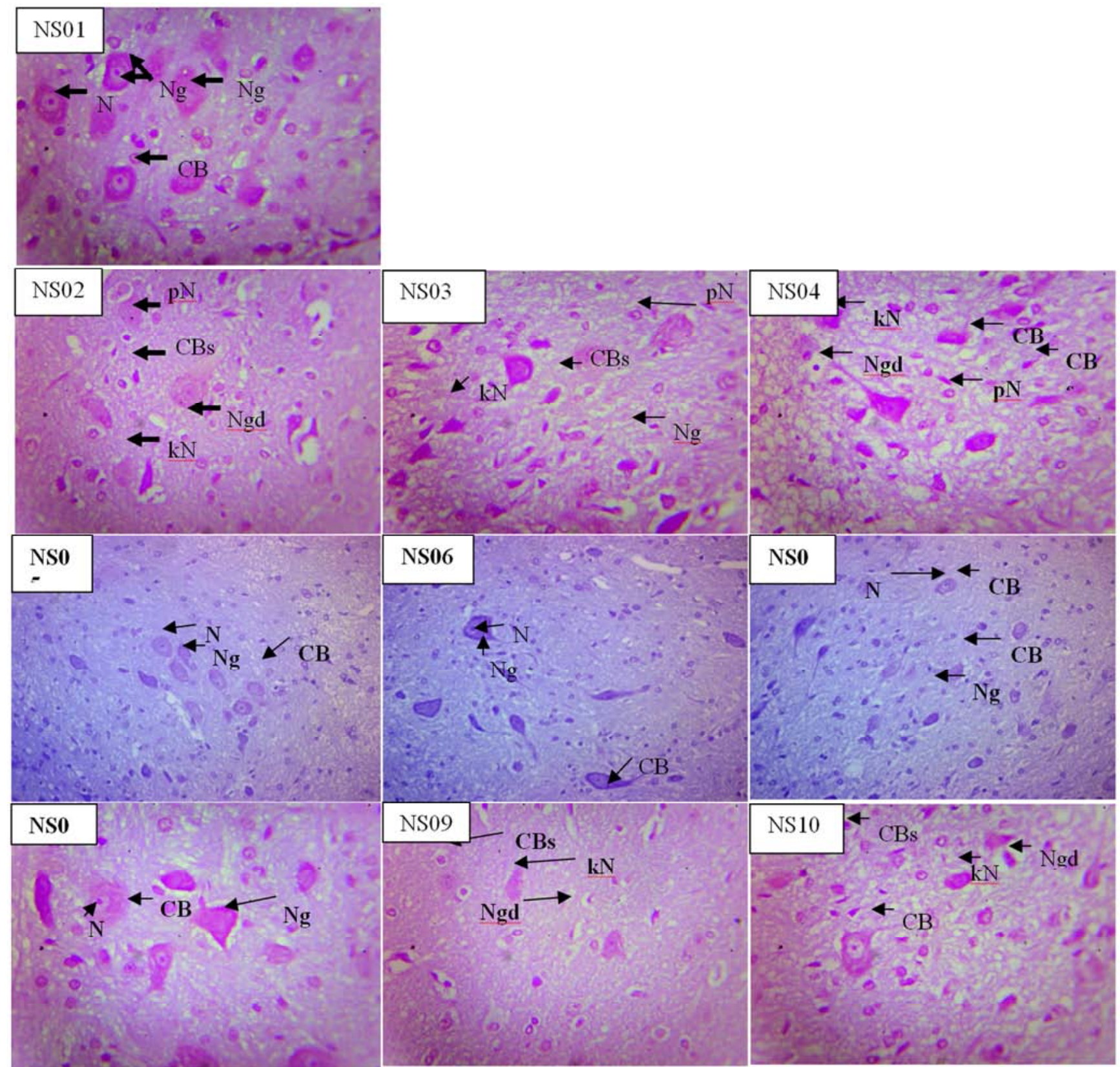

Figure 2. Photomicrographs of the inferior colliculus of experimental animals showing nissl substances and cellular cytoarchitecture following the administration of quinine and ethanol extract of Moringa oleifera. Pyknotic Nucleus shrinkage (pN); Karyolitic Nucleus (kN); Nissl granules depletion (Ngd); neuron cell body (CB); Nissl granules (Ng); cell body shrinkage (CBs); Nucleus (N). (CFV Histological Method, Mag X400).

Photomicrographs NS01 - NS10 represent histology of Groups $1-10$ respectively. Group 1 - Control; Group $2-10 \mathrm{mg} / \mathrm{kg}$ of quinine; Group $3-20 \mathrm{mg} / \mathrm{kg}$ of quinine; Group $4-30 \mathrm{mg} / \mathrm{kg}$ of quinine; Group $5-250 \mathrm{mg} / \mathrm{kg}$ of M. oleifera; Group $6-500 \mathrm{mg} / \mathrm{kg}$ of M. oleifera; Group $7-750 \mathrm{mg} / \mathrm{kg}$ of M. oleifera; Group $8-10 \mathrm{mg} / \mathrm{kg}$ of quinine and $250 \mathrm{mg} / \mathrm{kg}$ of $M$. oleifera concomitantly; Group $9-20 \mathrm{mg} / \mathrm{kg}$ of quinine and $500 \mathrm{mg} / \mathrm{kg}$ of M. oleifera concomitantly; Group $10-30 \mathrm{mg} / \mathrm{kg}$ of quinine and $750 \mathrm{mg} / \mathrm{kg}$ of $M$. oleifera concomitantly. 


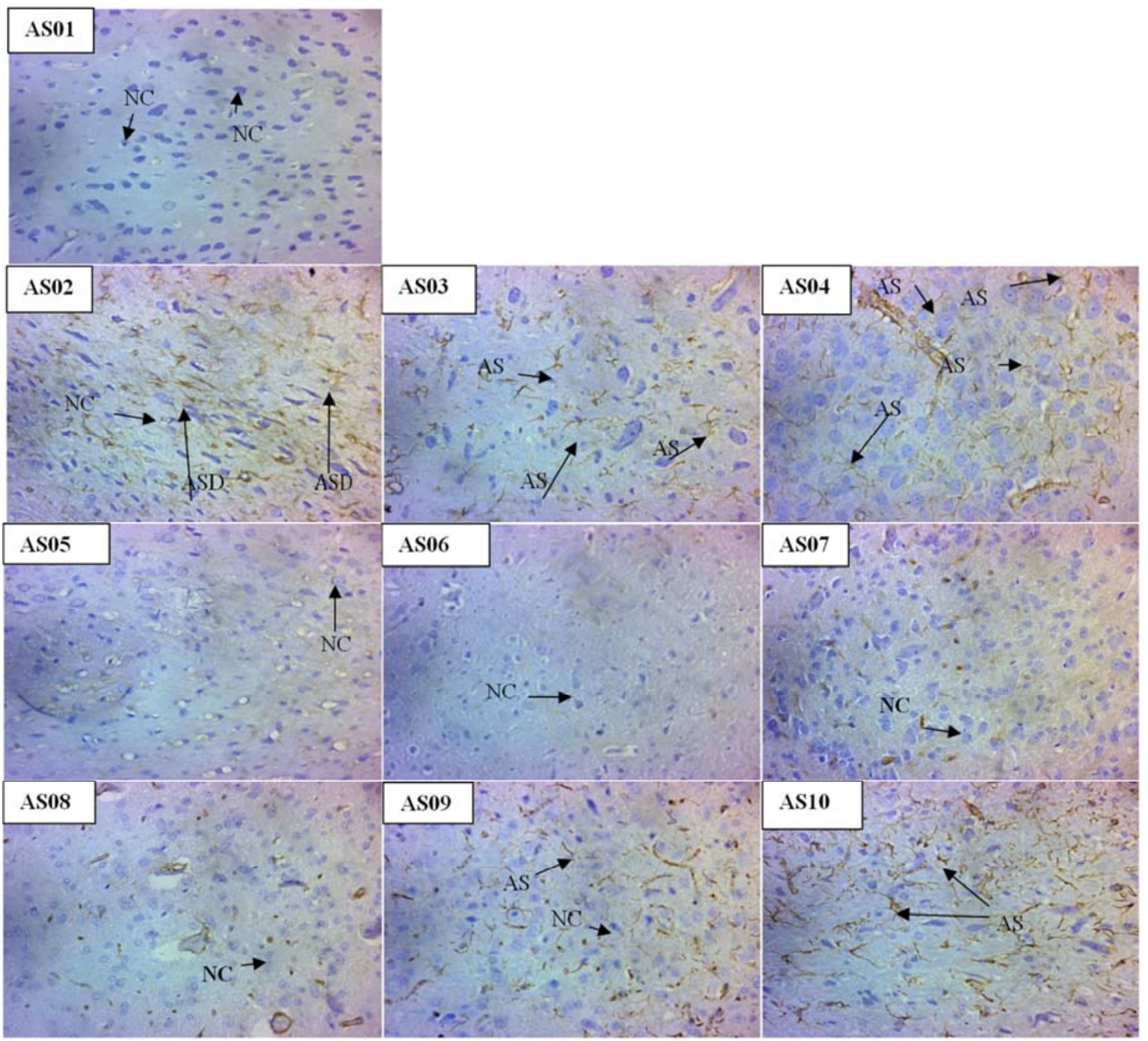

Figure 3. Photomicrographs of the Immunohistochemistry of the inferior colliculus of experimental animals showing astrocyte reactivity following the administration of quinine and ethanol extract of Moringa oleifera. Astrocytes (AS); neuronal cell (NC).(GFAP Immunohistochemistry Method; Mag. X400).

Photomicrographs AS01 - AS10 represent histology of Groups 1 - 10 respectively. Group 1 - Control; Group $2-10 \mathrm{mg} / \mathrm{kg}$ of quinine; Group 3 - $20 \mathrm{mg} / \mathrm{kg}$ of quinine; Group $4-30 \mathrm{mg} / \mathrm{kg}$ of quinine; Group $5-250 \mathrm{mg} / \mathrm{kg}$ of $M$. oleifera; Group $6-500 \mathrm{mg} / \mathrm{kg}$ of M. oleifera; Group $7-750 \mathrm{mg} / \mathrm{kg}$ of $M$. oleifera; Group $8-10 \mathrm{mg} / \mathrm{kg}$ of quinine and $250 \mathrm{mg} / \mathrm{kg}$ of $M$. oleifera concomitantly; Group $9-20 \mathrm{mg} / \mathrm{kg}$ of quinine and $500 \mathrm{mg} / \mathrm{kg}$ of $M$. oleifera concomitantly; Group $10-30 \mathrm{mg} / \mathrm{kg}$ of quinine and $750 \mathrm{mg} / \mathrm{kg}$ of $M$. oleifera concomitantly.

\section{Lipid peroxidation (IU/L)}

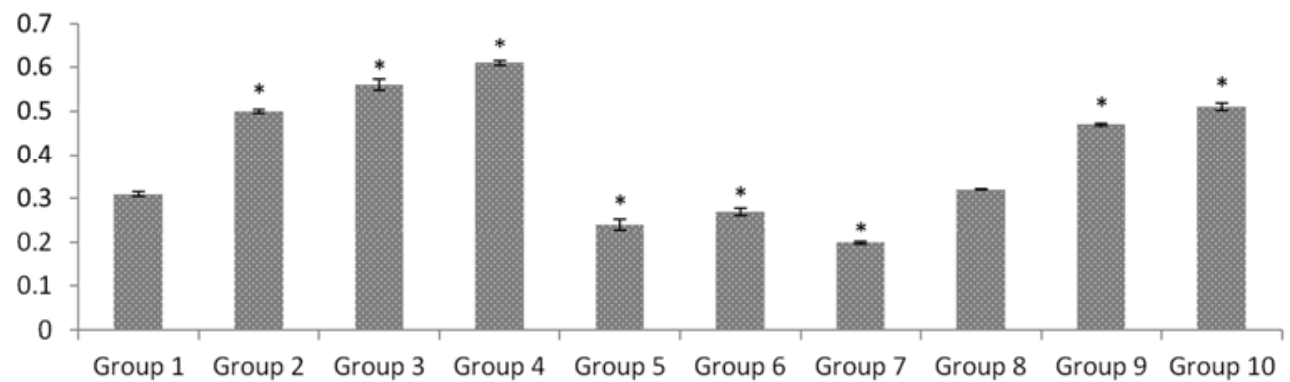

Figure 4. The effect of ethanol leaf extract of M. oleifera and quinine on lipid peroxidation (LPO) of albino Wistar rats. Values presented Mean \pm SEM. *=significantly different when compared to control group at p <0.01. Group 1 - Control; Group $2-10 \mathrm{mg} / \mathrm{kg}$ of quinine; Group $3-20 \mathrm{mg} / \mathrm{kg}$ of quinine; Group $4-30 \mathrm{mg} / \mathrm{kg}$ of quinine; Group $5-250 \mathrm{mg} / \mathrm{kg}$ of M. oleifera; Group $6-500 \mathrm{mg} / \mathrm{kg}$ of M. oleifera; Group $7-750 \mathrm{mg} / \mathrm{kg}$ of M. oleifera; Group $8-10$ $\mathrm{mg} / \mathrm{kg}$ of quinine and $250 \mathrm{mg} / \mathrm{kg}$ of M. oleifera concomitantly; Group $9-20 \mathrm{mg} / \mathrm{kg}$ of quinine and $500 \mathrm{mg} / \mathrm{kg}$ of M. oleifera concomitantly; Group $10-30$ $\mathrm{mg} / \mathrm{kg}$ of quinine and $750 \mathrm{mg} / \mathrm{kg}$ of M. oleifera concomitantly. 


\section{SUPEROXIDE DISMUTASE (IU/L)}

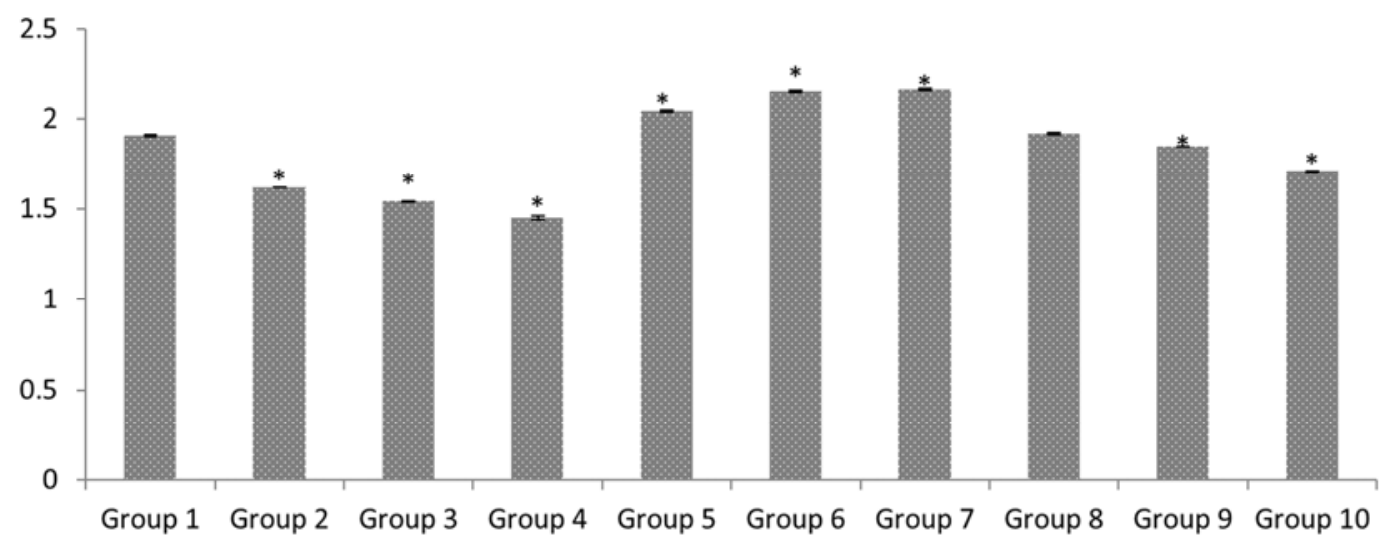

Figure 5. The effect of ethanol leaf extract of M. oleifera and quinine on peroxide dismutase activity (SOD) of albino Wistar rats. Values presented Mean \pm SEM. *=significantly different when compared to control group at $p<0.01$. Group 1 - Control; Group $2-10 \mathrm{mg} / \mathrm{kg}$ of quinine; Group $3-20 \mathrm{mg} / \mathrm{kg}$ of quinine; Group 4-30 mg/kg of quinine; Group 5 - $250 \mathrm{mg} / \mathrm{kg}$ of M. oleifera; Group 6-500 mg/kg of M. oleifera; Group $7-750 \mathrm{mg} / \mathrm{kg}$ of M. oleifera; Group $8-10 \mathrm{mg} / \mathrm{kg}$ of quinine and $250 \mathrm{mg} / \mathrm{kg}$ of M. oleifera concomitantly; Group $9-20 \mathrm{mg} / \mathrm{kg}$ of quinine and $500 \mathrm{mg} / \mathrm{kg}$ of M. oleifera concomitantly; Group 10 $30 \mathrm{mg} / \mathrm{kg}$ of quinine and $750 \mathrm{mg} / \mathrm{kg}$ of M. oleifera concomitantly.

\section{CATALASE ACTIVITY (IU/L)}

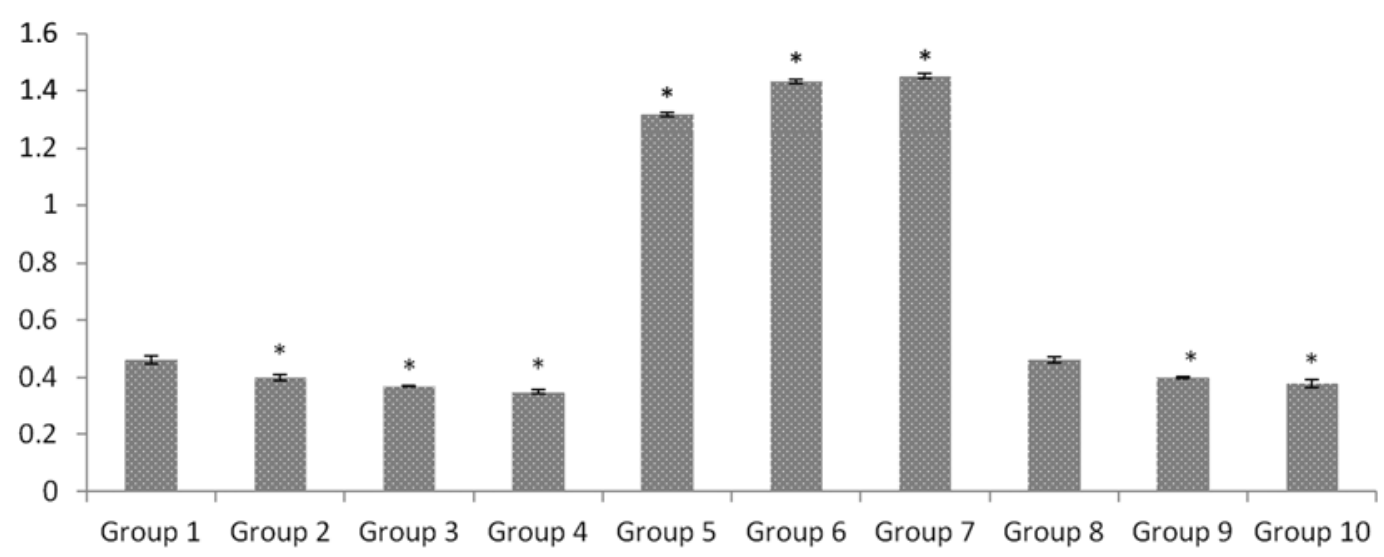

Figure 6. The effect of ethanol leaf extract of M. oleifera and quinine on catalase activity (CAT) of albino Wistar rats. Values presented Mean \pm SEM. *=significantly different when compared to control group at $p<0.01$. Group 1 - Control; Group $2-10 \mathrm{mg} / \mathrm{kg}$ of quinine; Group $3-20 \mathrm{mg} / \mathrm{kg}$ of quinine; Group $4-30 \mathrm{mg} / \mathrm{kg}$ of quinine; Group $5-250 \mathrm{mg} / \mathrm{kg}$ of M. oleifera; Group 6-500 mg/kg of M. oleifera; Group $7-750 \mathrm{mg} / \mathrm{kg}$ of M. oleifera; Group $8-10$ $\mathrm{mg} / \mathrm{kg}$ of quinine and $250 \mathrm{mg} / \mathrm{kg}$ of M. oleifera concomitantly; Group $9-20 \mathrm{mg} / \mathrm{kg}$ of quinine and $500 \mathrm{mg} / \mathrm{kg}$ of M. oleifera concomitantly; Group $10-30$ $\mathrm{mg} / \mathrm{kg}$ of quinine and $750 \mathrm{mg} / \mathrm{kg}$ of M. oleifera concomitantly.

\section{Discussion}

Medicinal plants can be used in different form, as raw materials for the extraction of active compounds or for the extraction of abundant but inactive constituents which can be transformed by partial synthesis into active compounds, as drugs or extracts or traditional preparations [16]. Medicinal Plants are therapeutics resource much used by the population of the world specifically for health care [24]. World-wide interest in the use of medicinal and aromatic plants is increasing. Beneficial effects of plant based medicines and other plant based products are being rediscovered. Different parts of Moringa oleifera have been used for the treatment of inflammation, infectious diseases, cardiovascular, gastrointestinal, haematological and hepatorenal disorders
$[25,26]$. Quinine is an alkaloid derived from the bark of the cinchona tree that is used in the treatment of malaria. Several toxic effect have been observed following quinine administration and they include tinnitus, slight impairment of hearing, headache and nausea. The metabolite of quinine (3hydroxyquinine) is of higher toxicity and it is also likely that 3-hydroxyquinine contributes to adverse effects, the toxicity observed or felt during quinine administration [27]. Based on the aforementioned, the ameliorative effect of ethanol leaf extract of Moringa oleifera on the oxidative stress and inferior colliculus of albino rats intoxicated with quinine was evaluated in the present study.

The present study demonstrated that quinine exhibited a deleterious effect on the inferior colliculus of rats as observed in quinine treated groups (Groups 2, 3 and 4). From the result, the changes of astrocytic phenotype were mild, moderate and 
severe as shown in Groups 2, 3 and 4 treated with 10, 20 and $30 \mathrm{mg} / \mathrm{kg}$ bw of quinine respectively. The changes are based on the capacity of matured cells to undergo a switch in response to an insult and it essentially characterized by upregulation of intermediate filament protein [28]. Quinine might actually be the key to initiate internal process that optimizes neuronal cells and conditions them to prepare for damaging effect. In this study, quinine could have acted as toxins to the cells of the inferior colliculus, affecting their cellular integrity and causing a defect in membrane permeability and cell volume homeostasis. Quinine is known to cross membranes by simple diffusion, thus getting access to the cells [4]. This property of quinine could have been one of the causes of the degenerative changes observed in this study. In cellular necrosis, the rate of progression depends on the severity of environmental insults.

The prime candidates for inducing the massive cell destruction observed in neuro-degeneration are neurotoxins [11]. These may be substances present in small amounts in the environment, or even naturally occurring chemicals such as glutamate used by the brain as transmitter substances [13]. The latter, when present at a critical level, can be toxic to the brain cells they normally excite $[13,29]$. The decrease in neuronal density of quinine treated group as reported in this study may have been as a result of cell death caused by the toxic effect of quinine [4]. A study by Ajibade et al., [30] corroborates the observed neuronal degeneration in association with loss of Nissl bodies and reduced staining intensity of the nissl substances in the inferior colliculus of quinine treated rats in the present study. Ajibade et al., [30] had reported similar cyto-architectural changes in the cerebral cortex following the administration of quinine to adult Wistar rats. Furthermore, loss of Nissl substance and shrinkage of the nucleus in dogs have been reported following intramuscular administration of artemether [31]. Injury to axons or neuronal exhaustion, resulting from strong or prolonged stimuli, causes a reduction in the number of Nissl bodies. This alteration, which is called chromatolysis, occurs simultaneously with nuclear migration to the periphery of the perikaryon [13], and consequently the RNA level is reduced. Chemical and toxic substances affect the Nissl substance thereby influencing their metabolic activity [13]. Similarly, it has been reported that neuronal degeneration causes a reduction in Nissl bodies [1]. Neuronal degeneration in quinine-treated rats has already been reported by [30].

Consequently, reduced staining intensity of the Nissl substance in the inferior colliculus of the treated rats may be due to neuronal pathology, following the neurotoxic effect of quinine. It is possible that quinine had an irreversible effect on the Nissl substances of the inferior colliculus, bringing about such microstructural changes in the neurons which manifested as degeneration and loss of Nissl substances with reduced staining intensity of the Nissl substances in the inferior colliculus of the quinine-treated rats. Degeneration and loss of Nissl substances may consequently affect the synthesis of both structural protein and protein for transport in correlation with neuronal functions. The reduced neurogenesis and increased cell death can all cause or be the result of neuro-degenerative changes [2].

However the GFAP immunoreactivity in quinine treated group suggests that quinine showed earlier astrocytes response. Quinine induced degeneration in the inferior colliculus result in diffused astrogliosis. Astroglial persist throughout the period of quinine administration. Thus astrocytes reactivity was up-regulated during quinine administration. Astrocytes reactivity is heterogeneous with differential phenotypes dependent upon the inducing stimulus [32]. Although quinine specific mechanism of action resulting in demyelination is still unclear, quinine has been shown to induce a stress response in oligodendrocytes [32].

Moringa oleifera leaf extract did not produce any histologically observed deleterious effect on the inferior colliculus. A positive effect of $M$. oleifera leaf extracton other brain tissues such as cerebral cortex has been reported [33]. The polyphenolic compound of the leaf extracts might have played a vital role. It has been reported that the plant polyphenols provide protection against neurodegenerative changes [34]. Based on the effect of polyphenolic compound just mentioned, it was also possible that the neuroprotective of the plant extract was associated with these compounds.

In the present study, the effect of quinine and Moringa oleifera leaf extract concurrent administration on the inferior colliculus of rats in the group administered $10 \mathrm{mg} / \mathrm{kg}$ of quinine and $250 \mathrm{mg} / \mathrm{kg}$ of $M$. oleifera leaf extract concomitantly revealed normal features. This is an indication that the structural damage that occur in the inferior colliculus of rats which received $10 \mathrm{mg} / \mathrm{kg}$ of quinine was absent following administration of the extract. This points to the evidence that $M$. oleifera was able to restore to normal, the structural damage caused by low dose of quinine on the inferior colliculus. Anti-toxicity effect of $M$. oleifera leaf extract on cerebral cortex has been reported [35]. M. oleifera leaf extracts exhibited the ability to provide neurite protection, in other words it protects against structural damage. This is reflected by preservation to or close to normal in terms of morphological structures as observed in $10 \mathrm{mg} / \mathrm{kg}$ of quinine and $250 \mathrm{mg} / \mathrm{kg}$ of $M$. oleifera concomitantly treated group. The presence of neurogenic agent such as $M$. oleifera leaf extracts could ameliorate the process by providing a positive stimulation while damping the neurodegenerative effect of quinine and prevent erratic uncoordinated stimulation.

Observations in Groups $9(20 \mathrm{mg} / \mathrm{kg}$ of quinine and 500 $\mathrm{mg} / \mathrm{kg}$ of $M$. oleifera concomitantly) and $10(30 \mathrm{mg} / \mathrm{kg}$ of quinine and $750 \mathrm{mg} / \mathrm{kg}$ of $M$. oleifera concomitantly) revealed that structural damage occur on the inferior colliculus of rats in these groups. Comparison between treated groups revealed normal inferior colliculus morphology in Group $8(10 \mathrm{mg} / \mathrm{kg}$ of quinine and $250 \mathrm{mg} / \mathrm{kg}$ of $M$. oleifera concomitantly) compared with Group 2 (10 $\mathrm{mg} / \mathrm{kg}$ of quinine) which showed degenerative changes. Inferior colliculus of animals in Group $3(20 \mathrm{mg} / \mathrm{kg}$ of quinine) revealed a moderate degeneration compared with Group $9(20 \mathrm{mg} / \mathrm{kg}$ of quinine and $500 \mathrm{mg} / \mathrm{kg}$ of $M$. oleifera concomitantly) which showed mild degenerative changes. 
Inferior colliculus of animals in Group $4(30 \mathrm{mg} / \mathrm{kg}$ of quinine) showed a severe neurodegeneration compared with Group $10(30 \mathrm{mg} / \mathrm{kg}$ of quinine and $750 \mathrm{mg} / \mathrm{kg}$ of $M$. oleifera concomitantly) which revealed a mild neurodegeneration. These are indications of the neuroprotective effect of Moringa oleifera leaf extract, thus damping the neurodegenerative effect of quinine dose dependent.

Reactive oxygen species (ROS) are related to oxidative stress and many scientific reports have shown that excessive production of reactive oxygen species (ROS) can further aggravate oxidative stress and have complicated ROS in number of disorder and disease processes [36, 37]. The equilibrium between the reactive oxygen stress (ROS) and antioxidant enzymes including superoxide dismutase (SOD) and catalase (CAT) are crucial and could be an important mechanism for preventing damage by oxidative stress. Antioxidants appear to act against disease processes by increasing the level of endogenous antioxidant enzyme such as SOD and CAT and decreasing toxic byproducts of lipid peroxidation such as malondialdehyde [38]. Malondialdehyde (MDA) is one of the end products of polyunsaturated fatty acid peroxidation and it is a good indicator of the degree of lipid peroxidation which is related to quinine-induced tissue damage [12].

The reduction in SOD and CAT activities with increased in the level of MDA in the pathogenesis of quinine intoxication as observed in Group 2 (10 mg/kg of quinine), $3(20 \mathrm{mg} / \mathrm{kg}$ of quinine), $9(20 \mathrm{mg} / \mathrm{kg}$ of quinine and $500 \mathrm{mg} / \mathrm{kg}$ of Moringa oleifera concomitantly) and $10(30 \mathrm{mg} / \mathrm{kg}$ of quinine and 750 $\mathrm{mg} / \mathrm{kg}$ of Moringa oleifera concomitantly) indicate oxidative stress. The decreased enzymatic activity in turn enhanced the excess reactive oxygen species (ROS) resulting in increased in oxidative damage reflected in the elevation of MDA leading to neurodegeneration. The increase in MDA level could be due to a reduction in antioxidant defense. A decrease in SOD production can be attributed to enhanced superoxide generation and utilization of this enzyme during reactive metabolites detoxification. The antioxidant enzyme SOD is the first line of defense against reactive oxygen species, converting them to toxic hydrogen peroxide in living tissue. Catalase (CAT) further carries out the detoxification of hydrogen peroxide to molecules of oxygen and water. Similar changes in the activities of antioxidant enzymes have been reported by Verma et al., [39] and Wu et al., [11] following administration of drugs.

Moringa oleifera leaf extracts enhanced SOD and CAT activity and decreased MDA level. This is consistent with recent report that $M$. oleifera increased the antioxidant enzymatic activities and decreased lipid peroxidation in Swiss albino mice [31]. These suggest that the extract may act as radical chain terminator and transforms free radical species to stable non-reactive product [39]. The highly protective effect of Moringa oleifera against neurotoxicity induced drugs has previously been studied [34]. This points to a conclusive evidence that the protective effect of $M$. oleifera leaf extract on SOD and MDA concentration may be attributed to the presence of phyto-constituent particularly flavonoids and polyphenols that scavenge free radicals, activate the antioxidant enzymes and inhibit oxidation [33]. Based on these results, it may be suggested that the therapeutic potentials of $M$. oleifera leaf extract are dependent on the antioxidant mechanism.

\section{Conclusion}

In conclusion, the present study has shown that quinine induced neurodegeneration manifesting as altered cytoarchitecture of inferior colliculus, depletion of nissl granules and increased astrocytes reactivity in the experimental animal. Quinine dose dependent toxicity of the inferior colliculus may be through the mechanism of free radicals generation leading to oxidative stress. The product of lipid peroxidation increased in a dose dependent manner coupled with decreased activity of the antioxidant enzymes with quinine administration. $M$. oleifera leaf extract however, showed a protective effect against quinine induced neuronal toxicity in albino Wistar rats. Restoration of normal cytoarchitecture of the inferior colliculus was observed following the administration of $M$. oleifera. Ethanol leaf extract of $M$. oleifera further increased the activities of superoxide dismutase and catalase while inhibiting the generation of free radicals as reflected in the reduced concentration of the product of lipid peroxidation. The administration of high doses of quinine should be discouraged and Moringa oleifera may be administered as an adjuvant during quinine therapy to ameliorate its toxicity.

\section{References}

[1] Meo SD, Reed TT, Venditti P, Victor VM. Harmful and Beneficial role of ROS. Oxidative Medicine and Cellular Longevity, 2018; 1-2.

[2] Pizzaro G, Irrera N, Cucinotta M, Pallio G, Federica M, Arcoraci V, Squadrito F, Altavilla D, Bitto A. Oxidative stress: Harms and Benefits for Human health. Oxidative Medicine and Cellular Longevity, 2017; 13.

[3] World Health Organization. Guidelines for the Treatment of Malaria. $2^{\text {nd }}$ Edition Geneva: WHO, 2010; pp. 19-21.1/10/15.

[4] Achan J, Tibenderana J, Kyabyinze D, Mawejje H, Mugizi R, Mpeka B, Talisuna A, D'Alessandro U. Case Management of Severe Malaria- a Forgotten Practice: experiences from health facilities in Uganda. Plos One, 2011; 6 (3): e1705.

[5] Jane A, Ambrose O, Talisuna A, Adoke Y, James K, Frederick N, Philip J, D'Alessandro A. Quinine, an Old Antimalaria Drug in a Modern World: role in the treatment of malaria. Malaria Journal, 2011; 10, 144-156.

[6] Looareesuwan S, OosterrhuisB, Schilizzi BM., Sollie FA, Wilairatana P, Krudsood S. Dose-finding and Efficacy Study for I. M. artemotil (beta-arteether) and Comparison with Artemether in acute Uncomplicated P. falciparum Malaria. British Journal of Clinical Pharmacology, 2002; 53, 492500. 
[7] Ogbunugafor H, Igwo-Ezikpe U, Ozumba N, Aderekav S, Ugochukwu C, Onyekwelu O, Ekeehi A. In vitro and in vivo Evaluation of Antioxidant Properties of MoringaoleiferaEthanolic Leaves Extract and Effect on Serum Lipid Indices in Rats. International Journal of Medical Sciences. 2012; 5 (4): 397-403.

[8] Middleton E Jr, Kandaswami C, Theoharides TC. The Effects of Plant Flavonoids on Mammalian cells: Implications for inflammation, heart disease cancer. Pharmacological Reviews, 2000; 52, 673-751.

[9] Sofidiya MO, Odukoya OA, Familoni OB, Inya-Agha SI. Free Radical Scavenging Activity of some Nigerian Medicinal Plant Extracts. Pakistan Journal of Biological Sciences, 2006; 9, 1438-1441.

[10] Adesegun SA, Elechi NA, Coker HAB. Antioxidant Activities of Methanolic Extract of Sapiumelliticum. Pakistan Journal of Biological Sciences, 2008; 11, 453-457.

[11] Wu JQ, Kosten TR, Zhang XY. Free radicals, antioxidant defense system, and schizophrenia. Progress of Neuropsychopharmacology and Biological Psychiatry, 2013; 46: 200-206.

[12] Navarro-Yepes J, Zavala-Flores L, Anandhan A, Wang F, Skotak M, Chandra N. Antioxidant gene therapy against neuronal cell death. Pharmacology and Therapeutics, 2014; 142: 206-230

[13] Ilesanmi F, Akinloye O, Ilesanmi O. Comparative evaluation of in vitro antioxidant properties of Cajanuscayan seed and Moringa oleifera leaf extracts. International Journal of Biochemical Research and Review 2014; 4 (2): 453-474.

[14] Ranira G, Rimi H, Kanshik R, Debajani G. Effect of Moringaoleifera in Experimental Model of Alzheimer's Disease: Role of antioxidants. Annual of Neuroscience, 2005; 12: 3 .

[15] Vergara-Jimenez M, Almatrafi MM, Fernandez ML. Bioactive components in Moringaoleifera leaves protect against chronic disease. Antioxidants, 2017; 6 (4): 91.

[16] Saini RK, Sivanesan I, Keum Y. Phytochemicals of Moringaoleifera: A review of their nutritional therapeutics and industrial significance. Biotechnology, 2016; 6 (2): 203.

[17] Lorke D. A New Approach to Tropical Acute Toxicity Testing. Archive of Toxicoloy, 1983; 53: 275-287.

[18] Herbert GA. Hippurate Hydrolysis by Legionella Pneumophila. Journal of Clinical Microbiology, 1981; 13: 240-242.

[19] Beers RF, Jr. Sizer W. Aspectrophotometric Method for Measuring the Breakdown of Hydrogen Peroxide by Catalase. Journal of Biological Chemistry, 1952; 195: 133-140.

[20] Kakkar P, Das B, Viswanathan PN. A Modified Spectrophotometric Assay of Superoxide Dismutase. Indian Journal of Biochemical and Biophysics, 1984; 21 (2): 130-132.

[21] Nichaus WG, Samuelsson B. Formation of Malondialdehyde from Phospholipid Arachidonate during Microsomal Lipid Peroxidation. European Journal of Biochemistry, 1968; 6: 126-130.

[22] Kawamura S, Niimi K. Counterstaining of Nauta-Gygax Impregnated Sections with Cresyl Violet. Stain Technology,
1972; 47: 1.

[23] Steel RGD, Torrie JH. Principles and Procedures of Statistics. (With special Reference to the Biological Sciences.). New York: McGraw-Hill Book Company, 1980; pp. 81-86.

[24] Akpan EJ. Phytochemical and Nutraceuticals in Health Affair: The Biochemical Perspective. Uyo: University of Uyo Press, 2014; pp 10-15.

[25] Morimitsu Y, Hayashi K, Nakagama Y, Horio F, Uchida K, Osawa T. Antiplatelet and anticancer isothiocyanates in Japanese horseradish, wasabi. Biology Factors, 2000; 13: 271-276.

[26] Siddhuraju P, Becker K. Antioxidant Properties of various Solvent Extracts of Total Phenolic Constituents from three different Agro-climatic Origins of Drumstick Tree (MoringaoleiferaLam.). Journal of Agricultural and Food Chemistry, 2003; 15: 2144-2155.

[27] Newton P, Keeratithakul D, Teja-Isavadharm P, Pukrittayakamee S, Kyle D, White N. Pharmacokinetics of Quinine and 3-Hydroxyquinine in Severe Falciparum Malaria with Acute Renal Failure. Journal of Transactions of the Royal Society Tropical Medicine Hygiene, 1999; 93: 69-72.

[28] Nahirnyi A, Livne-Bar I, Guo X, Sovak JM. ROS Detoxification and Proinflammatory Cytokines are linked by p38 MAPK Signaling in a Model of Mature Astrocyte Activation. A Peer Review, Open Access Journal, 2013; 8 (12) 258-278.

[29] Umoh IU, Ekanem AU, Bassey UE, Ufot AL. Ameliorative Effect of Moringa Oleifera Leaves Extract on the Intracranial Auditory Relay Centre (Inferior Colliculus) of Male Albino Wistar Rats with Quinine Induced Toxicity. International Journal of Pharmaceutical Research and Applications, 2017; 2 (1): 10-15.

[30] Ajibade AJ, Adenowo TK, Fegemilehin ME, Caxton-Martins EA, Omotoso EO. Some Histological Observation on the Cerebellar Cortex of Adult Wistar Rats Following Quinine Administration. Science Focus, 2006; 11: 97-100.

[31] Luqman S, Srivastava S, Kumar R, Maurya AK, Chanda D. Experimental Assessment of Moringaoleifera Leaf and Fruit for its Antistress, Antioxidant, and Scavenging Potential using in Vitro and in Vivo Assays, Evidence-Based Complementary and Alternative Medicine, 2012; Article ID 519084.

[32] Zamarian L, Sinz E, Bonatti N, Gamboz N, Delazer M. Normal Aging Affects Decisions under Ambiguity, but not Decisions under Risk. Neuropsychology, 2012; 22: 645-657.

[33] Gupta RG, Kannan M, Sharma M, Flora SJ. Plants Natural Antioxidants. In: National Proceedings Radiance, 2005; 5: 326-334.

[34] Simonyi BT. Effects of Plants Polyphenols in Nervous Tissue. Journal of Neuroscience, 2005; 45: 578-597.

[35] Owolabi J, Williams F. Histological Assessment of Moringaoleifera Anti-Toxicity Actions against Lead-Induced Damage to the Cerebellar Cortex in Animal Models. International Journal of Moringa and Nutriceutical Research, 2014; 1 (1): 75-84.

[36] Giordano FJ. Oxygen, Oxidative Stress, Hypoxia, and Heart Failure. Journal of Clinical Investigations, 2005; 115: 500-508. 
[37] Sies H, Stahl W, Sevanian A. Nutritional, Dietary and Postprandial Oxidative Stress. Journal of Nutrition, 2005; 135: 969-972.

[38] Bansal AK, Bansal M, Soni G, Bhatnagar D. Protective Role of Vitamin E Pre-treatment on N-nitrosodiethylamine Induced Oxidative Stress in Rat Liver. Chemical Biology Interactions, 2005; 156; 101-111.
[39] Verma AR. Jayakumar M, Mathela CS, Rao CV. In Vitro and In Vivo Anti-oxidant Properties of Different Fractions of MoringaoleiferaLeaves. Journal of Food Chemistry and Toxicology, 2009; 47: 2196-2201. 